San Antonio Review • San Antonio Review (Issue 2 | Winter 2019)

\title{
Men Without Hearts, Inc.
}

\author{
Alex Z. Salinas ${ }^{1}$ \\ ${ }^{1}$ San Antonio Review
}

Published on: Oct 30, 2019

Updated on: Sep 17, 2020

DOI: $10.21428 / 9 b 43 c d 98.0 d d d 56 e 2$

License: Creative Commons Attribution 4.0 International License (CC-BY 4.0). 


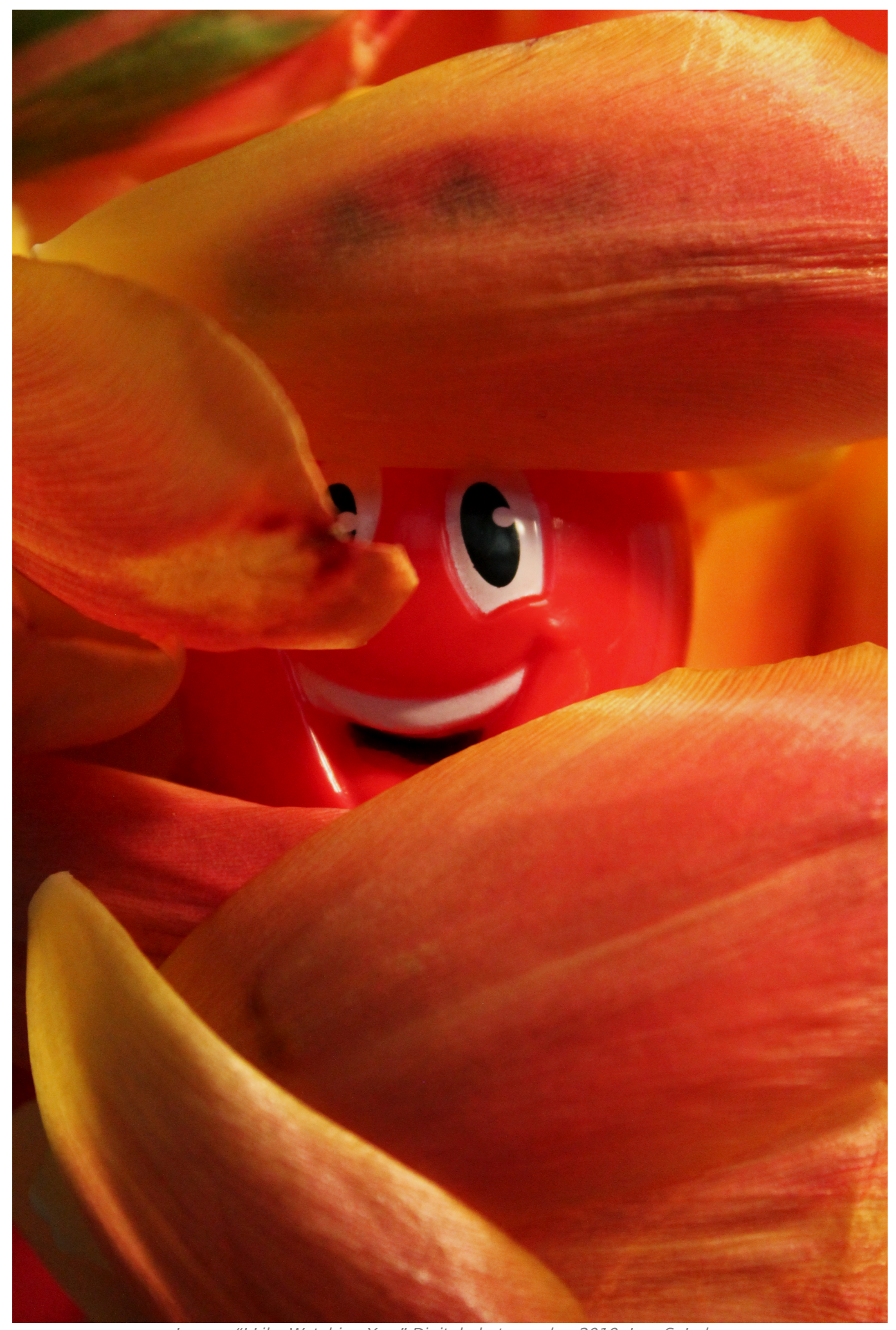

Image: "I Like Watching You," Digital photography, 2019, Jury S. Judge 
They say when you fall in love, you give her a piece of your heart. So when things go bad, and she's gone, you lose a piece of yourself - forever.

I agree with all that except I never gave Luz a piece of my heart; no, she took it, pillaged the whole beating bleeding thing like a Viqueen. Well, I let her.

My punishment for leaving my chest wide open is living without a heart.

Outside, it's getting dark, raining heavily. The golden hour's fading. The lights are on upstairs, and I'm upstairs sitting on my father's favorite rocking chair. Rocking.

Don't ask if I'm home. The worst question is the kind whose answer is obvious. A purloined letter kind of question.

When I got a letter in the mail, an invitation/application to join Men Without Hearts, Inc., I was eager to sign up, send them their requested $\$ 250$ annual club fee. Basically, all the money I had to my name.

If you'll recall, Biggie Smalls once said, "Mo' money, mo' problems." My motto has always been, "No money, no problems!"

The invitation said in two to three months, after payment is received, the club would ship me a piece of some poor sap's chemically treated heart in the form of a pill - a little chewable - so I could feel something, anything, again.

Hooray.

Until then, I had to wander Earth without a core.

Without a ticker to match the rhythm of my footsteps, or at the very least provide me a beat to tap my foot to, time was relative, irrelevant-yesterday's newspaper in the hands of an actuary.

In other words, I had all the time in the world, and nowhere to dump it.

I miss her body, the way she filled out her Levi's, the way she let me slide my hands under her blouse, run my greedy fingers up and down her dark curves, lick her salty-sweet Luz skin, give her goosebumps. 
I miss her mind, that shadowy jungle, the way Luz chuckled at kids in restaurants choking on foodnaughty girl-and the way she got dead-serious gazing at lonely old men in diners shuffle off to the restroom. “Their time's up, baby, and ours has just beguneth," I'd tell her in these saturated situations. She'd look at me with slitted eyes, blazing lips, and respond with something to the tune of, "You talk like an amateur hedonist, honey, a boy who's yet to grow into his own fur." My arms and legs were only mildly hairy.

I had to admit: the girl was deep.

I miss her farts, silent but deadly, always while I drove, always her devilish grin a sign of her Catholic guilt.

I miss her smile, her straight white teeth - her long thin neck I could wrap my hands around, gently. I miss being King of her Mind, Body \& Soul. My one true Viqueen.

Luz.

It's been four months and still no package. I'm obsessed with waiting for the mail. I can tell that Daryl, my postman, is frightened to death of me. He probably wishes I were dead. Some days I think I am. It could be my breath. Brushing my teeth again, flossing, might help my case. Listerine strips, too, if I could afford them.

It could also be the gaping hole in my chest, the very wound Daryl was transfixed by.

“This?" I said, thumbing to it. "This is just a significant chasm in my center. An empty tomb. You can poke it if you want. It doesn't really hurt anymore."

"You craycee, mayne, you craycee," Daryl said, taking a step backwards.

"Why Dare-Dare," I said, stepping toward him, reaching out to pat his shoulder.

“Don't you touch me, craycee mayne!"

Yet my palm had already found its desired destination.

Five months. 
I've been ripped off. Scammed. There's no magical capsule coming. I'm a victim of my own problems of hoaxes, schemes, conspiracies and pilfered adoration.

I must wander this earth without a core. That's my punishment.

Ever heard of Hammurabi's Code? Universal law? Karmic justice? Cosmic indifference? Chaos theory?

Yeah, yeah, yeah. Hate to break it to you, sweetie, but those are just fancy labels for "Tough fucking luck."

Six months.

Wandering.

Broke.

Broke and heartless. Heartless and broke-don't know which combination sounds better. My beard is big and poofy. My body's skinny, twig-like, stinks something awful too, according to the masses.

What's my age again? I don't remember. It's easier to forget than you might think.

What's there left to register?

Aha, registers! Ka-ching.

I could have all the money and jewels in the world, but still no core. No girl.

Cold. I'm very cold.

Did I mention it barely stopped raining this morning?

Today, I met some kids at the park. They stared at my chest, seemed impressionable enough.

“There's nothing there for you to see, children, so look into my eyes!" I shouted. "Here's your lesson for today: When heartless, hold on tight to your money!"

They all made like sissy bananas and split.

Me, I stayed put, looked up at the sky, spotted the sun peeking out of the clouds finally. 
“Hey there, Mr. Sol," I announced. "It's good to see you, been a while.”

Then it hit me: Talking warmed me up, replaced stagnant vapors in my body with a fresh breeze as though the ocean was around the corner. It was exactly what the doctor had ordered, and it felt incredible-felt incredible to feel incredible!

Now I just needed to recalibrate my inside-voice. Tackle one problem at a time. Yeah. That was plenty of work to keep a mere mortal busy.

Alex Z. Salinas lives in San Antonio. He was the inaugural poetry editor for San Antonio Review.

Jury S. Judge is an internationally published artist, writer, poet, photographer and political cartoonist. Her Astronomy Comedy cartoons are also published in The Lowell Observer. Her artwork has been featured in literary magazines such as_ Dodging The Rain, The New Plains Review, The Ignatian Literary Magazine and Fearsome Critters. She graduated Magna Cum Laude with a BFA from the University of Houston-Clear Lake in 2014. 